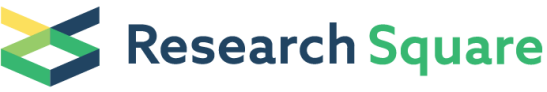 \\ Preprints are preliminary reports that have not undergone peer review. \\ They should not be considered conclusive, used to inform clinical practice, \\ or referenced by the media as validated information.
}

\section{Genotyping and subtyping of Cryptosporidium spp. and Giardia duodenalis isolates from two wild rodent species in Gansu Province, China}

\section{Jie Xu}

National Institute of Parasitic Diseases, Chinese Center for Disease Control and Prevention(Chinese Center for Tropical Diseases Research)

Hua Liu

National Institute of Parasitic Diseases, Chinese Center for Disease Control and Prevention(Chinese Center for Tropical Diseases Research)

\section{Yanyan Jiang}

National Institute of Parasitic Diseases, Chinese Center for Disease Control and Prevention(Chinese Center for Tropical Diseases Research)

\section{Huaiqi Jing}

National Institute of Infectious Diseases, Chinese Center for Disease Control and Prevention

\section{Jianping Cao}

National Institute of Parasitic Diseases, Chinese Center for Disease Control and Prevention(Chinese Center for Tropical Diseases Research)

Jianhai Yin

National Institute of Parasitic Diseases, Chinese Center for Disease Control and Prevention(Chinese Center for Tropical Diseases Research)

\section{Teng Li}

National Institute of Parasitic Diseases, Chinese Center for Disease Control and Prevention(Chinese Center for Tropical Diseases Research)

\section{Yeting Sun}

National Institute of Parasitic Diseases, Chinese Center for Disease Control and Prevention(Chinese Center for Tropical Diseases Research)

\section{Xin Wang}

National Institute of Infectious Diseases, Chinese Center for Disease Control and Prevention

\section{Yujuan Shen ( $\nabla$ shenyj@nipd.chinacdc.cn )}

National Institute of Parasitic Diseases, Chinese Center for Disease Control and Prevention(Chinese Center for Tropical Diseases Research)

\section{Research Article}


Keywords: Cryptosporidium spp., Giardia duodenalis, Himalayan marmots, Alashan ground squirrels, Genotyping, Subtyping

Posted Date: October 25th, 2021

DOI: https://doi.org/10.21203/rs.3.rs-992850/v1

License: (c) (i) This work is licensed under a Creative Commons Attribution 4.0 International License. Read Full License 


\section{Abstract}

Cryptosporidium spp. and Giardia duodenalis are common detected intestinal protozoa species in humans and animals, contributing to global gastroenteritis spread. In the present study, we examined the prevalence and zoonotic potential of Cryptosporidium spp. and G. duodenalis in two rodent species in Qinghai-Tibetan Plateau area (QTPA) of China for the first time. A total of 498 intestinal content samples were collected from five counties of QTPA of Gansu province, China. Cryptosporidium spp. and G. duodenalis were found in $2.5 \%(10 / 399)$ and $1.5 \%$ (6/399) of Himalayan marmots, while in $1.0 \%(1 / 99)$ and $2.0 \%(2 / 99)$ of Alashan ground squirrels, respectively. Four Cryptosporidium genotypes were identified, including one known horse genotype $(n=1)$ and three novel genotypes designated as marmot genotype I $(n=7)$, marmot genotype II $(n=2)$ and marmot genotype III $(n=1)$. The horse genotype was further subtyped as novel subtype VIbA10. G. duodenalis zoonotic assemblages $A(n=1), B(n=6), E(n=1)$ were identified in the present study. This is the first study to identify Cryptosporidium spp. and G. duodenalis in the two wild rodent species worldwide, suggesting the potential zoonotic transmission of the two pathogens in QTPA.

\section{Introduction}

Cryptosporidium spp. and Giardia duodenalis are critical protozoan parasites responsible for diarrhea, and infect a wide range of hosts including humans worldwide. Typically, contaminated food or water has been identified as the main vehicle for Cryptosporidium spp. and G. duodenalis transmission [1, 2]. Infection can also be acquired following contact with infected persons or animals directly $[2,3]$.

Currently, at least 45 valid Cryptosporidium spp. species and over 100 genotypes have been identified. Over 22 Cryptosporidium species/genotypes have been identified in humans, and $C$. hominis and $C$. parvum are the most common species (more than $90 \%$ ) responsible for human cryptosporidiosis [4-11]. G. duodenalis is a complex protozoan species, and it has been divided into at least eight genetically different assemblages $(A-H)$ on the basis of genetic characterization. Among them, assemblage $A$ and $B$ are considered to be the important zoonotic pathogens. Assemblages $(\mathrm{C}-\mathrm{H})$ are more host-specific: assemblages $C$ and $D$ in canines, assemblage $E$ in cloven-hoofed mammals, assemblage $F$ in cats, assemblage $\mathrm{G}$ in rodents, and assemblage $\mathrm{H}$ in seals [12]. However, assemblages $\mathrm{C}, \mathrm{D}, \mathrm{E}$ and $\mathrm{F}$ have been also found in humans [13].

Rodents can play an important role in the transmission of a large number of zoonotic pathogens, including bacteria, parasites and viruses. These animals may act as important sources of infection in humans, animals and the environment. Himalayan marmots (Marmota himalayana) and Alashan ground squirrels (Spermophilus alashanicus) are two common wild rodent species distributed widely in the Qinghai-Tibetan Plateau area (QTPA) of China. They typically reside near livestock, water sources and human environments, infected hosts can play an important role in environmental contamination by excreting oocysts/cysts via faeces [14]. Some epidemiological studies also revealed the identity of Cryptosporidium spp. and $G$. duodenalis in numerous investigated hosts in QTPA, such as wild Qinghai voles, plateau pikas, wild birds, cattle, yaks, sheep [15-19]. Furthermore, the zoonotic species and genotypes of Cryptosporidium spp. and G. duodenalis were also reported in environmental samples in QTPA, including sewage and river water, 
slaughter house water and vegetables from street markets $[14,20]$. However, no study about the prevalence and transmission of Cryptosporidium spp. and G. duodenalis in Himalayan marmots and Alashan ground squirrels in China was reported before. In the present study, a cross-sectional investigation of the two protozoa was carried out in two wild rodent species to understand the prevalence of Cryptosporidium spp. and $G$. duodenalis and to assess the zoonotic potential at the genotype and subtype levels.

\section{Materials And Methods}

\section{Ethics Statement}

All animals were handled in strict accordance with good animal practice according to the Animal Ethics Procedures and Guidelines of the People's Republic of China, and the study was approved by the Laboratory Animal Welfare \& Ethics Committee of National Institute of Parasitic Diseases, Chinese Center for Disease Control and Prevention, China, (Permit No: IPD-2016-15). In addition, all methods were carried out in accordance with relevant guidelines, and all authors complied with the ARRIVE guidelines.

\section{Sample Collection}

During a period of three months from June to September 2017, 399 marmots and 99 ground squirrels were captured live by mousetraps from QTPA of western China's Gansu Province, with the former from Luqu $(n=98)$, Sunan $(n=100)$, Xiahe $(n=102)$ and Zhangye $(n=99)$ and latter from Huining County $(n=99)$ (Table 1). These animals were euthanized with a high dose of $\mathrm{CO}_{2}$ in accordance with security measures. Intestinal content materials were directly collected from each animal in the laboratory of the local Center for Disease Control and Prevention (CDC) and placed in $2 \mathrm{ml}$ sterile tubes. They were kept in a freezer and then transported in ice packs to our laboratory in Shanghai for further molecular analysis.

Table 1 Prevalence and molecular identification of Cryptosporidium spp. and G. duodenalis by rodent species and collection site. 


\begin{tabular}{|c|c|c|c|c|c|c|c|c|}
\hline \multirow{3}{*}{$\begin{array}{l}\text { Rodent } \\
\text { species }\end{array}$} & \multirow{3}{*}{$\begin{array}{l}\text { Collection } \\
\text { site }\end{array}$} & \multirow{3}{*}{$\begin{array}{l}\text { No. } \\
\text { examined }\end{array}$} & \multicolumn{2}{|c|}{ Cryptosporidium spp. } & \multicolumn{4}{|c|}{ G. duodenalis } \\
\hline & & & \multirow{2}{*}{$\begin{array}{l}\text { No. } \\
\text { positive } \\
(\%)\end{array}$} & \multirow{2}{*}{$\begin{array}{l}\text { Genotype } \\
\text { (n) } \\
\text { SSU } \\
\text { rRNA }\end{array}$} & \multirow{2}{*}{$\begin{array}{l}\text { Subtype } \\
\text { (n) } \\
\text { gp60 }\end{array}$} & \multirow{2}{*}{$\begin{array}{l}\text { No. } \\
\text { positive } \\
(\%)\end{array}$} & \multicolumn{2}{|c|}{$\begin{array}{l}\text { Assemblage } \\
\text { (n) }\end{array}$} \\
\hline & & & & & & & gdh & bg \\
\hline \multirow{4}{*}{$\begin{array}{l}\text { Himalayan } \\
\text { marmot } \\
\text { (Marmota } \\
\text { himalayana) }\end{array}$} & Luqu & 98 & 0 & - & - & 0 & - & - \\
\hline & Sunan & 100 & $7(7.0)$ & $\begin{array}{l}\text { marmot } \\
\text { genotype } \\
\text { I a }(5) ;_{\text {marmot }} \\
\text { genotype } \\
\text { II a }(1) ;_{\text {marmot }} \\
\text { genotype } \\
\text { III a }^{\text {a }}(1)\end{array}$ & - & 0 & - & - \\
\hline & Xiahe & 102 & $2(2.0)$ & $\begin{array}{l}\text { marmot } \\
\text { genotype } \\
\mathrm{I}^{\mathrm{a}}(2)\end{array}$ & - & $3(2.9)$ & $\begin{array}{l}B \\
(1), \\
E \\
(1)\end{array}$ & $\begin{array}{l}\mathrm{B} \\
(2), \\
\mathrm{E}^{\mathrm{a}} \\
(1)\end{array}$ \\
\hline & Zhangye & 99 & $1(1.0)$ & $\begin{array}{l}\text { marmot } \\
\text { genotype } \\
\|^{\text {a }}(1)\end{array}$ & - & $3(3.0)$ & $\begin{array}{l}B \\
(1)\end{array}$ & $\begin{array}{l}\text { A } \\
(1) \\
B(1)\end{array}$ \\
\hline Subtotal & & 399 & $10(2.5)$ & & - & $6(1.5)$ & $\begin{array}{l}B \\
(2), \\
E \\
(1)\end{array}$ & $\begin{array}{l}\text { A } \\
(1), \\
\text { B } \\
(3), E \\
\text { a (1) }\end{array}$ \\
\hline $\begin{array}{l}\text { Alashan } \\
\text { ground } \\
\text { squirrel } \\
\text { (Spermophilus } \\
\text { alaschanicus) }\end{array}$ & Huining & 99 & $1(1.0)$ & $\begin{array}{l}\text { horse } \\
\text { genotype } \\
(1)\end{array}$ & $\begin{array}{l}\text { VIbA10 } \\
\text { b (1) }\end{array}$ & $2(2.0)$ & $\begin{array}{l}\text { B } \\
(2)\end{array}$ & B (2) \\
\hline Total & & 498 & $11(2.2)$ & $\begin{array}{l}\text { marmot } \\
\text { genotype } \\
\text { I a }^{\text {a }}(7) ; \\
\text { marmot } \\
\text { genotype } \\
\text { II a }(2) ; \\
\text { marmot } \\
\text { genotype } \\
\text { III a }(1) ;_{\text {horse }} \\
\text { genotype } \\
\text { (1) }\end{array}$ & $\begin{array}{l}\text { VIbA10 } \\
\text { b (1) }\end{array}$ & $8(1.6)$ & $\begin{array}{l}\text { B } \\
(4) \\
E \\
(1)\end{array}$ & $\begin{array}{l}\text { A } \\
(1), \\
B \\
(5), \\
E^{a} \\
(1)\end{array}$ \\
\hline
\end{tabular}

a: novel genotype 
b: novel subtype

\section{DNA Extraction}

Genomic DNA was extracted using the DNeasy Blood \& Tissue Kit (Cat. \#69506; Qiagen, Hilden, Germany) according to the manufacturer's instructions. Extracted DNA was stored at $-20^{\circ} \mathrm{C}$ in a freezer until further use.

\section{PCR Amplification}

Cryptosporidium spp. were detected by nested PCR amplification of the fragment (approximately 830bp) of the small subunit (SSU) rRNA gene [21]. Subtyping of Cryptosporidium spp. was performed by a sequence analysis of the $60 \mathrm{kDa}$ glycoprotein (gp60) gene [22]. The assemblages of $G$. duodenalis were identified and subtyped by amplifying the $\beta$-giardin $(b g)$, glutamate dehydrogenase ( $g d h)$ [23-25]. Positive and negative controls were used for the primary and secondary PCR tests to ensure accuracy of PCR tests. The secondary PCR products were visualized under UV light after electrophoresis on a 1.5\% agarose gel containing GelRed (Biotium Inc., Hayward, CA, USA).

\section{Nucleotide Analysis}

All secondary PCR amplicons of the expected size were sequenced on ABI 3730 DNA Analyzer (Applied Biosystems, Foster City, USA) and Big Dye Terminator v3.1 Cycle Sequencing Kit (Applied Biosystems). Sequence accuracy was confirmed by bi-directional sequencing of all the PCR-positive products. Obtained DNA sequences were aligned with reference sequences deposited in GenBank databases (http://www.ncbi.nlm.nih.gov) using Clustal X (http://www.clustal.org/) to determine the species/subtypes of Cryptosporidium spp. and assemblages of G. duodenalis.

\section{Results}

Prevalence of Cryptosporidium spp. and G. duodenalis

By PCR amplification and sequence analysis, Cryptosporidium spp. and G. duodenalis were both found in two wild rodent species. In total, $2.2 \%(11 / 498)$ and $1.6 \%$ (8/498) of intestinal content DNA samples were positive for Cryptosporidium spp. and G. duodenalis in these two animals, respectively, with $2.5 \%(10 / 399)$ and $1.5 \%$ (6/399) in Himalayan marmots, and 1.0\% (1/99) and 2.0\% (2/99) in Alashan ground squirrels (Table 1). Cryptosporidium spp. and G. duodenalis were detected in four and three sites, respectively. Different prevalences of both parasites were observed in two rodent species from different collection sites (Table 1).

\section{Cryptosporidium Genotypes and Subtypes}

Based on sequence analysis of the SSU rRNA gene, four Cryptosporidium genotypes were identified out of 11 isolates, including one known horse genotype $(n=1)$ in Alashan ground squirrels and three novel genotypes named as marmot genotype I (GenBank: MZ478131, $n=7$ ), marmot genotype II (GenBank: 
MZ478132, $\mathrm{n}=2$ ) and marmot genotype III (GenBank: MZ478133, $\mathrm{n}=1$ ) in Himalayan marmot samples. Cryptosporidium marmot genotype I was absolutely dominant in Himalayan marmots, which constituted the largest share $(70.0 \% ; 7 / 10)$ of Cryptosporidium isolates. At the SSU rRNA locus, the sequence of the horse genotype obtained in the present study had 100\% homology with a sequence (MK775040) from a horse in China. Seven sequences of the marmot genotype I were identical to each other and shared the largest similarity (98.29\%) to that (MF411075) of the skunk genotype in an eastern gray squirrel from Italy, with 17 base differences. The two same sequences of the marmot genotype II shared the largest identity (98.46\%) with that of $C$. rubeyi (DQ295012) from California ground squirrels in the USA, with 13 base differences. The sequence of the marmot genotype III had 99.00\% homology with that (MH940289) of the chipmunk genotype III from a red squirrel in China, with 13 base differences.

The Cryptosporidium horse genotype isolate was further subtyped by sequence analysis of gp60 gene. This subtype belonged to VIb subtype family, and were identified as VIbA10 (GenBank: MW531716).

\section{G. duodenalis Assemblages}

A total of eight $G$. duodenalis isolates were amplified and sequenced successfully in two rodent species. Assemblages A, B and E were identified in one, four and one Himalayan marmots, respectively. Assemblage $B$ was found in two Alashan ground squirrels. Meanwhile, assemblage B was observed to showed a predominance $(75.0 \%, 6 / 8)$ in the detected animals. The $g d h$ and $b g$ loci were successfully amplified in five samples-assemblages $B(n=4)$ and $E(n=1)$ and seven samples-assemblages $A(n=1), B(n=5)$ and $E$ $(n=1)$, respectively (Table 1$)$.

At the $g d h$ locus, two assemblage B sequences had $100 \%$ homology with beaver-derived assemblage B isolate (KM977648) of China, another two different assemblage B sequences were $100 \%$ identical to golden monkey-derived assemblage $B$ isolate (MK952602) in China, one assemblage E sequence was $100 \%$ identical to a pig-derived assemblage $E$ isolate (MK426742) from South Korea. At the $b g$ locus, five assemblage $B$ sequences shared $100 \%$ homology with squirrel monkey-derived assemblage $B$ isolate (KJ888974) from China, one assemblage A sequence had 100\% homology with human-derived assemblage A isolates (GQ329671) from Sweden and chipmunk-derived isolate (MF671918) from China, one assemblage E sequence (GenBank: MZ494459) shared the largest similarity (99.79\%) to that (KY633473) from a Tibetan sheep in China.

\section{Discussion}

In this study, the overall prevalence of Cryptosporidium spp. was 2.2\% (11/498), with $2.5 \%$ in Himalayan marmots, and $1.0 \%$ in Alashan ground squirrels. Other studies reported much higher prevalence of Cryptosporidium spp. in wild rodent species in China than this study, including in house mice $(3.2 \%, 1 / 31)$, long-tailed rats $(3.6 \%, 4 / 111$ and $55.3 \%, 21 / 38)$, brown rats $(6.3 \%, 4 / 64 ; 9.1 \%, 22 / 242$ and $28.6 \%, 16 / 56)$, wild plateau pikas $(6.3 \%, 4 / 64)$, Qinghai voles $(8.9 \%, 8 / 90)$, Asian house rats $(18.0 \%, 21 / 117 ; 18.2 \%, 6 / 33$ and $73.9 \%, 4 / 46)$, Brandt's voles $(18.7 \%, 127 / 678)$, Muridae $(40.0 \%, 4 / 10)[19,26-31]$. The prevalence in this study was also lower than that in some pet rodent species, including in bamboo rats $(3.3 \%, 3 / 92)$, 
Siberian hamsters $(7.8 \%, 4 / 51)$, red squirrels $(8.6 \%, 27 / 314$ and $26.3 \%, 5 / 19)$, Chichillas $(9.3 \%, 26 / 280)$, chinchillas $(10.0 \%, 14 / 140)$, campbell hamsters $(10.0 \%, 3 / 30$ and $22.2 \%, 6 / 27)$, Siberian chipmunks $(30.0 \%$, $6 / 20)$, gold hamsters $(32.0 \%, 16 / 50)$, chipmunks $(50.0 \%, 1 / 2$ and $75.0 \%, 3 / 4)$, guinea pigs $(52.3 \%, 162 / 310$ and $85.0 \%, 34 / 40)$, Roborovski dwarf hamsters $(100.0 \%, 1 / 1)$, and higher than that in pet red-bellied tree squirrels $(1.4 \%, 4 / 287)[28,32-37]$. In addition, there was difference between prevalence in different farmed and laboratory rodent species, including farmed bamboo rats $(2.1 \%, 9 / 435$ and $29.5 \%, 209 / 709)$, farmed brown rat $(7.1 \%, 12 / 168)$, experimental brown rats $(0.6 \%, 2 / 355)$, laboratory mouse $(1.7 \%, 4 / 229)$, laboratory rat $(4.0 \%, 1 / 25)[26,28,38-40]$. These variations in the prevalence of Cryptosporidium spp. in different studies may be explained by many factors, including the population densities, health status of hosts, management systems, experimental method and source region [41].

Altogether, four Cryptosporidium genotypes were identified in this study. One known horse genotype was originally isolated from a Prezewalski wild horse at the Prague Zoo in Czech Republic, and commonly detected in horses and donkeys, occasionally found in neonatal calves and hedgehogs $[42,43]$. It has also been found in human patients with diarrhea in the UK and USA, suggesting its zoonotic potential [44-46]. In the present study, horse genotype was identified in rodents for the first time, indicating it has a broader range of host range than initially anticipated. Horse genotype isolated from Alashan ground squirrels was further identified as novel subtype VIbA10. Currently, two subtype families are recognized within the Cryptosporidium horse genotype by sequence analysis targeting gp60 gene: Vla subtype family in animals (horses, donkeys and a calf, etc.) and VIb subtype family in humans and hedgehogs.

In addition, three novel Cryptosporidium genotypes (marmot genotype I, marmot genotype II and marmot genotype III) were also detected. To date, a total of 13 Cryptosporidium spp. species and 19 genotypes have been detected in 16 studies of various rodents in China, including those obtained in this study (Table 2) $[19,26-36,38-40]$. Among them, 11 species have been detected in humans: $C$. parvum, $C$. muris, $C$. ubiquitum, $C$. andersoni, $C$. occultus, $C$. viatorum, $C$. canis, $C$. suis, $C$. erinaceid, $C$. tyzzeri and horse genotype 4 . Indicating rodent species may play an important role in the transmission of zoonotic cryptosporidiosis. 
Table 2

Cryptosporidium species/genotypes in rodents in China.

\begin{tabular}{|c|c|c|c|c|}
\hline $\begin{array}{l}\text { Host species (Latin } \\
\text { name) }\end{array}$ & $\begin{array}{l}\text { No. positive } \\
\text { (\%) }\end{array}$ & Species/genotype (n) & $\begin{array}{l}\text { Sample } \\
\text { source }\end{array}$ & Ref \\
\hline $\begin{array}{l}\text { Alashan ground } \\
\text { squirrel } \\
\text { (Spermophilus } \\
\text { alaschanicus) }\end{array}$ & $1 / 99(1.0)$ & horse genotype (1) & wild & $\begin{array}{l}\text { this } \\
\text { study }\end{array}$ \\
\hline $\begin{array}{l}\text { Asian house rat } \\
\text { (Rattus tanezumi) }\end{array}$ & 6/33 (18.2) & C. parvum (3), C. muris (3) & wild & 26 \\
\hline $\begin{array}{l}\text { Asian house rat } \\
\text { (Rattus tanezumi) }\end{array}$ & 6/33 (18.2) & $\begin{array}{l}\text { C. tyzzer (1), rat genotype II (1), rat } \\
\text { genotype III (1), C. tyzzer+ rat genotype } \\
\text { II (1), C. tyzzer+ rat genotype III (1) }\end{array}$ & wild & 28 \\
\hline $\begin{array}{l}\text { Asian house rat } \\
\text { (Rattus tanezumi) }\end{array}$ & $\begin{array}{l}34 / 46 \\
(73.9)\end{array}$ & $\begin{array}{l}\text { rat genotype IV (24), rat genotype III (8), } \\
\text { C. occultus (1), C. erinacei (1) }\end{array}$ & wild & 31 \\
\hline $\begin{array}{l}\text { bamboo rats } \\
\text { (Rhizomys sinensis) }\end{array}$ & $9 / 435(2.1)$ & $\begin{array}{l}\text { bamboo rat genotype I (5), } C \text {. parvum } \\
\text { (2), C. occultus (1), bamboo rat } \\
\text { genotype II (1) }\end{array}$ & farmed & 39 \\
\hline $\begin{array}{l}\text { bamboo rats } \\
\text { (Rhizomys sinensis) }\end{array}$ & $3 / 92(3.3)$ & C. parvum (3) & pet & 33 \\
\hline $\begin{array}{l}\text { bamboo rats } \\
\text { (Rhizomys sinensis) }\end{array}$ & $\begin{array}{l}209 / 709 \\
(29.5)\end{array}$ & $\begin{array}{l}\text { C. ubiquitum-like (85), C. parvum (78), } \\
\text { C. parvum-like (45), C. occultus (1), }\end{array}$ & farmed & 40 \\
\hline $\begin{array}{l}\text { Brandt's vole } \\
\text { (Lasiopodomys } \\
\text { brandtii) }\end{array}$ & $\begin{array}{l}127 / 678 \\
(18.7)\end{array}$ & $\begin{array}{l}\text { C. suis, muskrat genotype II, Brandt's } \\
\text { voles genotype I }\end{array}$ & wild & 30 \\
\hline $\begin{array}{l}\text { brown rats (Rattus } \\
\text { norvegicus) }\end{array}$ & $4 / 64(6.3)$ & $\begin{array}{l}\text { C. tyzzer (3), C. tyzzer + rat genotype III } \\
\text { (1) }\end{array}$ & wild & 28 \\
\hline $\begin{array}{l}\text { brown rat (Rattus } \\
\text { norvegicus) }\end{array}$ & $\begin{array}{l}12 / 168 \\
(7.1)\end{array}$ & C. parvum (9), C. muris (3) & farmed & 26 \\
\hline $\begin{array}{l}\text { brown rats (Rattus } \\
\text { norvegicus) }\end{array}$ & $\begin{array}{l}22 / 242 \\
(9.1)\end{array}$ & $\begin{array}{l}\text { C. ratti (14), rat genotype IV (6), C. } \\
\text { occultus (1) }\end{array}$ & wild & 29 \\
\hline $\begin{array}{l}\text { brown rat (Rattus } \\
\text { norvegicus) }\end{array}$ & $\begin{array}{l}16 / 56 \\
(28.6)\end{array}$ & $\begin{array}{l}\text { rat genotype IV (13), C. muris (1), C. } \\
\text { occultus (1), rat genotype III (1) }\end{array}$ & wild & 31 \\
\hline $\begin{array}{l}\text { Campbell hamster } \\
\text { (Phodopus campbelli) }\end{array}$ & $3 / 30(10.0)$ & $\begin{array}{l}\text { C. parvum (1), C. andersoni (1), C. muris } \\
+ \text { C. parvum (1) }\end{array}$ & pet & 28 \\
\hline $\begin{array}{l}\text { Campbell hamster } \\
\text { (Phodopus campbelli) }\end{array}$ & $6 / 27(22.2)$ & hamster genotype (4), C. andersoni (2) & pet & 37 \\
\hline $\begin{array}{l}\text { Chichillas (Chinchilla } \\
\text { lanigera) }\end{array}$ & $\begin{array}{l}26 / 280 \\
(9.3)\end{array}$ & $\begin{array}{l}\text { C. ubiquitum (23), C. parvum (2), } \\
\text { chipmunk genotype V (1) }\end{array}$ & pet & 37 \\
\hline
\end{tabular}

Note: Plus signs indicate that the sample was co-infected with different Cryptosporidium species/genotypes. 


\begin{tabular}{|c|c|c|c|c|}
\hline $\begin{array}{l}\text { Host species (Latin } \\
\text { name) }\end{array}$ & $\begin{array}{l}\text { No. positive } \\
(\%)\end{array}$ & Species/genotype (n) & $\begin{array}{l}\text { Sample } \\
\text { source }\end{array}$ & Ref \\
\hline $\begin{array}{l}\text { Chipmunk (Eutamias } \\
\text { asiaticus) }\end{array}$ & $1 / 2(50.0)$ & ferret genotype (1) & pet & 36 \\
\hline $\begin{array}{l}\text { Chipmunk (Eutamias } \\
\text { asiaticus) }\end{array}$ & $3 / 4(75.0)$ & $\begin{array}{l}\text { ferret genotype (2), chipmunk genotype } \\
\vee(1)\end{array}$ & pet & 37 \\
\hline $\begin{array}{l}\text { Edward's long-tailed } \\
\text { rat (Leopoldamys } \\
\text { edwardsi) }\end{array}$ & $\begin{array}{l}21 / 38 \\
(55.3)\end{array}$ & $\begin{array}{l}\text { rat genotype IV (13), rat genotype III (1), } \\
\text { C. muris }(1), \text { C. occultus }(1)\end{array}$ & wild & 31 \\
\hline $\begin{array}{l}\text { experimental brown } \\
\text { rats (Ruttus } \\
\text { norvegicus) }\end{array}$ & $2 / 355(0.6)$ & $\begin{array}{l}\text { C. ubiquitum (1), undetermined } \\
\text { Cryptosporidium genotype (1) }\end{array}$ & laboratory & 38 \\
\hline $\begin{array}{l}\text { gold hamster } \\
\text { (Mesocricetu auratus) }\end{array}$ & $16 / 50(32.0)$ & $\begin{array}{l}\text { C. muris (6), C. andersoni (5), C. parvum } \\
\text { (2), C. muris + C. parvum (1), C. } \\
\text { andersoni + C. parvum (1) }\end{array}$ & et & 28 \\
\hline $\begin{array}{l}\text { guinea pig (Cavia } \\
\text { porcellus) }\end{array}$ & $\begin{array}{l}162 / 310 \\
(52.3)\end{array}$ & $\begin{array}{l}\text { C. wrairi (129), C. homai (32), C. muris } \\
\text { (1) }\end{array}$ & pet & 37 \\
\hline $\begin{array}{l}\text { guinea pig (Cavia } \\
\text { porcellus) }\end{array}$ & $\begin{array}{l}34 / 40 \\
(85.0)\end{array}$ & C. wrairi (30) & pet & 28 \\
\hline $\begin{array}{l}\text { Himalayan marmot } \\
\text { (Marmota } \\
\text { himalayana) }\end{array}$ & $\begin{array}{l}10 / 399 \\
(2.5)\end{array}$ & $\begin{array}{l}\text { Himalayan marmot genotype I (7), } \\
\text { Himalayan marmot genotype II (2), } \\
\text { Himalayan marmot genotype III (1) }\end{array}$ & wild & $\begin{array}{l}\text { this } \\
\text { study }\end{array}$ \\
\hline $\begin{array}{l}\text { house mouse (Mus } \\
\text { musculus) }\end{array}$ & $1 / 31(3.2)$ & C. muris (1) & wild & 26 \\
\hline $\begin{array}{l}\text { laboratory mouse } \\
\text { (Mus musculus) }\end{array}$ & $4 / 229(1.7)$ & C. tyzzer (4) & laboratory & 28 \\
\hline $\begin{array}{l}\text { laboratory rat (Rattus } \\
\text { norvegicus) }\end{array}$ & $1 / 25(4.0)$ & C. tyzzer (1) & laboratory & 28 \\
\hline $\begin{array}{l}\text { long-tailed rats } \\
\text { (Leopoldamys } \\
\text { edwardsi) }\end{array}$ & $4 / 111(3.6)$ & C. viatorum (4) & wild & 27 \\
\hline $\begin{array}{l}\text { Muridae (Niviventer } \\
\text { fulvescens) }\end{array}$ & $4 / 10(40.0)$ & rat genotype III (2), rat genotype IV (2) & wild & 31 \\
\hline $\begin{array}{l}\text { pet chinchillas } \\
\text { (Chinchilla lanigera) }\end{array}$ & $\begin{array}{l}14 / 140 \\
(10.0)\end{array}$ & C. ubiquitum (13), C. parvum (1) & pet & 35 \\
\hline $\begin{array}{l}\text { Qinghai vole } \\
\text { (Microtus fuscus) }\end{array}$ & $8 / 90(8.9)$ & $\begin{array}{l}\text { C. parvum (3), Qinghai vole genotype } \\
\text { (3), C. canis (1), C. ubiquitum (1) }\end{array}$ & wild & 19 \\
\hline $\begin{array}{l}\text { red-bellied tree } \\
\text { squirrels (Callosciurus } \\
\text { erythraeus) }\end{array}$ & $4 / 287(1.4)$ & $\begin{array}{l}\text { rat genotype II (2), C. parvum (1), C. } \\
\text { wrairi (1) }\end{array}$ & pet & 32 \\
\hline
\end{tabular}




\begin{tabular}{|c|c|c|c|c|}
\hline $\begin{array}{l}\text { Host species (Latin } \\
\text { name) }\end{array}$ & $\begin{array}{l}\text { No. positive } \\
\text { (\%) }\end{array}$ & Species/genotype (n) & $\begin{array}{l}\text { Sample } \\
\text { source }\end{array}$ & Ref \\
\hline $\begin{array}{l}\text { red squirrels (Sciurus } \\
\text { vulgaris) }\end{array}$ & $\begin{array}{l}27 / 314 \\
(8.6)\end{array}$ & $\begin{array}{l}\text { rat genotype II (8), ferret genotype (8), } \\
\text { chipmunk genotype III (5), C. ratti (4), C. } \\
\text { parvum (2) }\end{array}$ & pet & 34 \\
\hline $\begin{array}{l}\text { red squirrel (Sciurus } \\
\text { vulgaris) }\end{array}$ & $5 / 19(26.3)$ & ferret genotype (5) & pet & 28 \\
\hline $\begin{array}{l}\text { Roborovski dwarf } \\
\text { hamster (Phodopus } \\
\text { roborovskii) }\end{array}$ & $1 / 1(100)$ & C. muris (1) & pet & 37 \\
\hline $\begin{array}{l}\text { Siberian chipmunk } \\
\text { (Tamias sibiricus) }\end{array}$ & $6 / 20(30.0)$ & $\begin{array}{l}\text { ferret genotype (3), ferret genotype }+C \text {. } \\
\text { parvum (1), C. muris }+ \text { C. parvum }+ \\
\text { chipmunk genotype III (1) }\end{array}$ & pet & 28 \\
\hline $\begin{array}{l}\text { Siberian flying } \\
\text { squirrel (Pteromys } \\
\text { volans) }\end{array}$ & $1 / 1(100)$ & C. ubiquitum (1) & pet & 37 \\
\hline $\begin{array}{l}\text { Siberian hamster } \\
\text { (Phodopus sungorus) }\end{array}$ & $4 / 51(7.8)$ & $\begin{array}{l}\text { C. muris (1), C. parvum (1), C. andersoni } \\
+ \text { C. parvum (1), hamster genotype (1) }\end{array}$ & pet & 28 \\
\hline $\begin{array}{l}\text { Siberian hamster } \\
\text { (Phodopus sungorus) }\end{array}$ & $\begin{array}{l}32 / 37 \\
(86.5)\end{array}$ & hamster genotype (26),C. andersoni (6) & pet & 37 \\
\hline $\begin{array}{l}\text { Syrian hamster } \\
\text { (Mesocricetus } \\
\text { auratus) }\end{array}$ & $\begin{array}{l}26 / 30 \\
(86.7)\end{array}$ & C. andersoni (26) & pet & 37 \\
\hline $\begin{array}{l}\text { white-toothed rat } \\
\text { (Berylmys bowersi) }\end{array}$ & $\begin{array}{l}21 / 117 \\
(18.0)\end{array}$ & C. viatorum (21) & wild & 27 \\
\hline $\begin{array}{l}\text { wild plateau pika } \\
\text { (Ochotona curzoniae) }\end{array}$ & $4 / 64(6.3)$ & C. parvum (2), pika genotype (2) & wild & 19 \\
\hline
\end{tabular}

The present study detected the infection of two pathogens in two wild rodent species of the genus Marmota and genus Spermophilus. Further, eight previous studies have reported the occurrence of Cryptosporidium species/genotypes in other three species of the genus Marmota and other four species of genus Spermophilus: including $C$. ubiquitum in woodchuck (Marmota monax) in the USA [47, 48]; $C$. parvum in yellow-bellied marmot (Marmota flaviventris) in the USA[49]; C. andersoni in Bobak marmot (Marmota bobac) in the Czech Republic[42]; C. rubeyi in California ground squirrels (Spermophilus beecheyi) in the USA, Belding's ground squirrels (Spermophilus beldingi) and golden-mantled ground squirrels (Spermophilus lateralis) in the USA [50-52]; ground squirrel genotype I and ground squirrel genotype III in thirteen-lined ground squirrels (Spermophilus tridecemlineatus) in USA [53].

In this study, the overall prevalence of $G$. duodenalis was $1.6 \%$ (8/498), with $1.5 \%(6 / 399)$ for Himalayan marmots and 2.0\% (2/99) for Alashan ground squirrels, which are lower than that reported in rodents in 
China: house mouse $(3.2 \%, 1 / 31)$; Asian house rat $(6.1 \%, 2 / 33)$; brown rat $(6.6 \%, 11 / 168$ and $9.3 \%, 33 / 355)$; pet chipmunks $(8.6 \%, 24 / 279)$; bamboo rat $(10.8 \%, 52 / 480)$; coypus $(12.3 \%, 38 / 308)$; pet chinchillas $(27.1 \%, 38 / 140)[26,38,54-57]$ (Table 3).

Table 3

G. duodenalis assemblages in rodents in China.

\begin{tabular}{|c|c|c|c|c|c|c|}
\hline \multirow[t]{2}{*}{ Host species (Latin name) } & \multirow{2}{*}{$\begin{array}{l}\text { No. } \\
\text { positive } \\
\text { (\%) }\end{array}$} & \multicolumn{3}{|c|}{ Assemblage (n) } & \multirow{2}{*}{$\begin{array}{l}\text { Sample } \\
\text { source }\end{array}$} & \multirow[t]{2}{*}{ Ref } \\
\hline & & $b g$ & $g d h$ & tpi & & \\
\hline $\begin{array}{l}\text { Alashan ground squirrels } \\
\text { (Spermophilus alashanicus) }\end{array}$ & $\begin{array}{l}2 / 99 \\
(2.0)\end{array}$ & $B(2)$ & $B(2)$ & & wild & $\begin{array}{l}\text { this } \\
\text { study }\end{array}$ \\
\hline $\begin{array}{l}\text { Asian house rat (Rattus } \\
\text { tanezumi) }\end{array}$ & $\begin{array}{l}2 / 33 \\
(6.1)\end{array}$ & $\mathrm{G}(2)$ & $\mathrm{G}(1)$ & $\mathrm{G}(1)$ & wild & 26 \\
\hline bamboo rat (Rhizomys sinensis) & $\begin{array}{l}52 / 480 \\
(10.8)\end{array}$ & $B(52)$ & B (27) & $B(12)$ & farmed & 55 \\
\hline brown rat (Rattus norvegicus) & $\begin{array}{l}11 / 168 \\
(6 \cdot 6)\end{array}$ & $\mathrm{G}(11)$ & G (9) & G (10) & wild & 26 \\
\hline brown rat (Ruttus norvegicus) & $\begin{array}{l}33 / 355 \\
(9.3)\end{array}$ & G (19) & G (20) & G (21) & laboratory & 20 \\
\hline coypus (Myocastor coypus) & $\begin{array}{l}38 / 308 \\
(12.3)\end{array}$ & $\begin{array}{l}B(11), A \\
(1)\end{array}$ & $\begin{array}{l}\mathrm{B}(10) \\
\mathrm{A}(1)\end{array}$ & $\begin{array}{l}B(22) \\
A(3)\end{array}$ & farm & 57 \\
\hline $\begin{array}{l}\text { Himalayan marmots (Marmota } \\
\text { himalayana) }\end{array}$ & $\begin{array}{l}6 / 399 \\
(1.5)\end{array}$ & $\begin{array}{l}A(1), B \\
(3), E(1)\end{array}$ & $\begin{array}{l}\mathrm{B}(2) \\
\mathrm{E}(1)\end{array}$ & - & wild & $\begin{array}{l}\text { this } \\
\text { study }\end{array}$ \\
\hline house mouse (Mus musculus) & $\begin{array}{l}1 / 31 \\
(3.2)\end{array}$ & $\mathrm{G}(1)$ & - & $\mathrm{G}(1)$ & wild & 26 \\
\hline $\begin{array}{l}\text { pet chinchillas (Chinchilla } \\
\text { lanigera) }\end{array}$ & $\begin{array}{l}38 / 140 \\
(27.1)\end{array}$ & $\begin{array}{l}A(4), B \\
(8)\end{array}$ & $\begin{array}{l}A(4) \\
B(16)\end{array}$ & $\begin{array}{l}\text { A (3), } \\
\text { B (3) }\end{array}$ & pet & 35 \\
\hline $\begin{array}{l}\text { pet chipmunks (Eutamias } \\
\text { asiaticus) }\end{array}$ & $\begin{array}{l}24 / 279 \\
(8.6)\end{array}$ & $\begin{array}{l}G(11), A \\
(13)\end{array}$ & $\begin{array}{l}G(7) \\
A(10)\end{array}$ & $\begin{array}{l}G(4) \\
A(13)\end{array}$ & pet & 54 \\
\hline
\end{tabular}

In this study, the sequences of amplicons from $G$. duodenalis-positive samples were determined to be assemblages $A, B$, and $E$, with assemblage $B$ being more prevalent. Assemblages $A, B$ and $E$ were identified in Himalayan marmots and assemblage B in Alashan ground squirrels. G. duodenalis assemblages in Himalayan marmots were richer than Alashan ground squirrels. As we known, G. duodenalis infections in Chinese rodents were reported to be caused by assemblage A, B and $G$ in previous studies $[26,38,54-57]$. Among them, assemblages $A$ and $B$ have a broad host range and commonly found in humans [55]. In fact, some recent studies in China also reported the occurrence of assemblage Ain pet chipmunks, coypus and pet chinchillas, while assemblage Bin bamboo rat, coypus and pet chinchillas [54-57]. These two assemblages detected in this study, suggesting that these two rodent species can play a role in the zoonotic dissemination of $G$. duodenalis. Assemblage $E$ is commonly found in a range of hoofed livestock, it has also been found in human cases, indicating that this assemblage is of zoonotic significance [58]. 
And one recent study describes the occurrence of assemblage $E$ in a rodent species long-tailed chinchillas in Romania [59]. And in the present study, we characterized the appearances of assemblages $E$ in rodents in China for the first time, and identified a novel assemblage E sequence (GenBank: MZ494459), sequence comparison showed that this isolate had high homology with a known assemblages $E$ sequence available on GenBank (GenBank: KY633473), with only 1 base differences.

In the investigated areas of QTPA, wild rodent species Himalayan marmots and Alashan ground squirrels have strong migration habits and often share pasture with humans, herbivorous animals and other wild animals. Results of this study suggest that the two wild rodent species may play an important role in the transmission of Cryptosporidium spp. oocysts and G. duodenalis cysts among humans, animals, water sources and fresh produce in QTPA grassland ecosystem, and pose a threat to grassland ecosystem and public health.

\section{Conclusion}

To the best of our knowledge, this study examined the prevalence and zoonotic potential of Cryptosporidium spp. and G. duodenalis in two rodent species in Qinghai-Tibetan Plateau area (QTPA) of China for the first time. Four Cryptosporidium genotypes were identified, including one known horse genotype (novel subtype VIbA10), which was reported in rodent species firstly. And three novel genotypes: marmot genotype I, marmot genotype II and marmot genotype III. G. duodenalis zoonotic assemblages A, B, E were identified in this two rodent species. The results expanded the host range of Cryptosporidium spp. and $G$. duodenalis, providing more information on prevalence, epidemiology and genetic characterizations of the two pathogens in Himalayan marmots and Alashan ground squirrels. Further surveys are also required to understand the prevalence and transmission dynamics of the two pathogens, provide control and prevention strategies to reduce the risk to human and animals in the investigated area.

\section{Declarations}

\section{Acknowledgments}

We are grateful to Dr Daqin Xu at Gansu Provincial Centre for Disease Control and Prevention for help in collecting the samples.

\section{Author Contributions}

YS and XW designed the study. JX, HL, YJ, LT and YS participated in the sample collection and methodology. JX, HL, HJ and JY contributed to data analysis. YS and JC contributed reagents and materials. JX wrote the manuscript. YS and XW revised the manuscript. All authors read and approved the final manuscript.

\section{Competing interests}

The authors declare no competing interests. 


\section{Data Availability}

Nucleotide sequences of this article were deposited in the GenBank database under following accession numbers: MZ478131-MZ478133 (SSU rRNA), MW531716 (gp60) for Cryptosporidium; MZ494459 (bg) for G. duodenalis.

\section{Ethics statment}

This study was performed in strict accordance with the recommendations in the Guide for the Care and Use of Laboratory Animals of the National Institute of Parasitic Diseases, Chinese Center for Disease Control and Prevention. The protocol was approved by the Laboratory Animal Welfare \& Ethics Committee (LAWEC), National Institute of Parasitic Diseases, Chinese Center for Disease Control and Prevention (Permit Number: NIPD-2016-15).

\section{Funding}

This work was supported by the National Science and Technology Major Program of China (No. 2018ZX10713001-004 to YS), the National Natural Science Foundation of China(Nos. 82072307 and 81772224 to YS), and the Fifth Round of Three-Year Public Health Action Plan of Shanghai, China(No. GWV-10.1-XK13 to JC). The funders had no role in the study design, data collection and analysis, the decision to publish, or preparation of the manuscript.

\section{References}

1. Fayer, R. Cryptosporidium: a water-borne zoonotic parasite. Vet. Parasitol, 126, 37-56 (2004).

2. Feng, Y. \& Xiao, L. Zoonotic potential and molecular epidemiology of Giardia species and giardiasis. Clin. Microbiol. Rev, 24, 110-140 (2011).

3. Xiao, L. Molecular epidemiology of cryptosporidiosis: an update. Exp. Parasitol, 124, 80-89 (2010).

4. Feng, Y., Ryan, U. M. \& Xiao, L. Genetic diversity and population structure of. Cryptosporidium. Trends Parasitol, 34, 997-1011 (2018).

5. Holubová, N. et al. Cryptosporidiumproventriculi sp. n. (Apicomplexa: Cryptosporidiidae) in Psittaciformes birds. Eur. J. Protistol, 69, 70-87 (2019).

6. Holubová, N. et al. Description of Cryptosporidium ornithophilus n. sp. (Apicomplexa: Cryptosporidiidae) in farmed ostriches. Parasit. Vectors, 13, 340 (2020).

7. Bolland, S. J., Zahedi, A., Oskam, C., Murphy, B. \& Ryan U.Cryptosporidium bollandi n. sp. (Apicomplexa: Cryptosporidiiae) from angelfish (Pterophyllum scalare) and Oscar fish (Astronotus ocellatus). Exp. Parasitol, 217, 107956 https://doi.org/10.1016/j.exppara.2020.107956 (2020).

8. Ježková, J. et al. Cryptosporidium ratti n. sp. (Apicomplexa: Cryptosporidiidae) and genetic diversity of Cryptosporidium spp. in brown rats (Rattus norvegicus) in the Czech Republic., 148, 84-97 (2021).

9. Zahedi, A., Bolland, S. J., Oskam, C. L. \& Ryan U.Cryptosporidium abrahamseni n. sp. (Apicomplexa: Cryptosporidiiae) from red-eye tetra (Moenkhausia sanctaefilomenae). Exp. Parasitol, 223, 108089 
https://doi.org/10.1016/j.exppara.2021.108089 (2021).

10. Ježková, J. et al. Cryptosporidium myocastoris n. sp. (Apicomplexa: Cryptosporidiidae), the Species Adapted to the Nutria (Myocastor coypus). Microorganisms.9, 813(2021).

11. Fan, Y. et al. Subtyping Cryptosporidium xiaoi, a common pathogen in sheep and goats.Pathogens (Basel, Switzerland). 10,800(2021).

12. Xiao, L. \& \&Feng, Y. Molecular epidemiologic tools for waterborne pathogens Cryptosporidium spp. and Giardia duodenalis. Food. Waterborne. Parasitol, 8-9, 14-32 (2017).

13. Dixon, B. R. Giardia duodenalis in humans and animals - transmission and disease. Res. Vet. Sci, 135, 283-289 (2021).

14. Ma, L. et al. Detection of Cryptosporidium and Giardia in the slaughterhouse, sewage and river waters of the Qinghai Tibetan plateau area (QTPA), China. Parasitol. Res, 118, 2041-2051 (2019).

15. Jian, Y. et al. Occurrence of Cryptosporidium and Giardia in wild birds from Qinghai Lake on the Qinghai-Tibetan Plateau, China. Parasitol. Res, .120, 615-628 (2021).

16. Wu, Y. et al. Genotyping and identification of Cryptosporidium spp., Giardia duodenalis and Enterocytozoon bieneusi from free-range Tibetan yellow cattle and cattle-yak in Tibet, China. Acta. Tropica, 212, 05671 (2020).

17. Jian, Y. et al. Prevalence and molecular characterization of Giardia duodenalis in cattle and sheep from the Qinghai-Tibetan Plateau Area (QTPA), northwestern China. Vet. Parasitol, 250, 40-44 (2018).

18. Zhang, X. et al. Molecular detection and prevalence of Cryptosporidium spp. infections in two types of domestic farm animals in the Qinghai-Tibetan Plateau Area (QTPA) in China. Parasitol. Res, 117, 233239 (2018).

19. Zhang, X. et al. The first report of Cryptosporidium spp. in Microtus fuscus (Qinghai vole) and Ochotona curzoniae (wild plateau pika) in the Qinghai-Tibetan Plateau area, China. Parasitol. Res, 117, 1401-1407 (2018).

20. Li, X. et al. Detection of Cryptosporidium oocysts and Giardia cysts in vegetables from street markets from the Qinghai Tibetan Plateau Area in China. Parasitol. Res, 119, 847-1855 (2020).

21. Huang, D. et al. Establishment and application of PCR method for detection of Cryptosporidium, China [in Chinese]. Tropical. Med, 16, 8 (2016).

22. Alves, M. et al. Subgenotype analysis of Cryptosporidium isolates from humans, cattle, and zoo ruminants in Portugal. J. Clin. Microbiol, 41, 2744-2747 (2003).

23. Cacciò, S. M., Beck, R., Lalle, M., Marinculic, A. \& Pozio E.Multilocus genotyping of Giardia duodenalis reveals striking differences between assemblages A and B. Int. J. Parasitol, 38, 1523-1531 (2008).

24. Abe, N., Kimata, I. \& Iseki, M. Identification of genotypes of Giardia intestinalis isolates from dogs in Japan by direct sequencing of the PCR amplified glutamate dehydrogenase gene. J. Vet. Med. Sci, 65, 29-33 (2003).

25. Sulaiman, I. M. et al. Triosephosphate isomerase gene characterization and potential zoonotic transmission of Giardia duodenalis. Emerg. Infect. Dis, 9, 1444-1452 (2003). 
26. Zhao, Z. et al. Genotyping and subtyping of Giardia and Cryptosporidium isolates from commensal rodents in China., 142, 800-806 (2015).

27. Chen, Y. W. et al. Identification of Cryptosporidium viatorum XVa subtype family in two wild rat species in China. Parasit. Vectors, 12, 502 (2019).

28. Lv, C. et al. Cryptosporidium spp. in wild, laboratory, and pet rodents in china: prevalence and molecular characterization. Appl. Environ. Microbiol, 75, 7692-7699 (2009).

29. Zhao, W. et al. Molecular characterizations of Cryptosporidium spp. and Enterocytozoon bieneusi in brown rats (Rattus norvegicus) from Heilongjiang Province, China. Parasit. Vectors, 11, 313-313 (2018).

30. Feng, S. et al. Molecular Characterization of Cryptosporidium spp. in Brandt's Vole in China. Front. Vet. Sci, 7, 300 (2020).

31. Zhao, W. et al. Cryptosporidium spp. in wild rats (Rattus spp.) from the Hainan Province, China: molecular detection, species/genotype identification and implications for public health. Int. J. Parasitol. Parasites Wildl.9, 317-321(2019).

32. Chai, Y. et al. First detection of Cryptosporidium spp. in red-bellied tree squirrels (Callosciurus erythraeus) in China. Parasite, 26, 28 (2019).

33. Liu, X. et al. Occurrence of novel and rare subtype families of Cryptosporidium in bamboo rats (Rhizomys sinensis) in China. Vet. Parasitol, 207, 144-148 (2015).

34. Deng, L. et al. Occurrence and genetic characteristics of Cryptosporidium spp. and Enterocytozoon bieneusi in pet red squirrels (Sciurus vulgaris) in China. Sci. Rep, 10, 1026 (2020).

35. Qi, M. et al. Zoonotic Cryptosporidium spp. and Enterocytozoon bieneusi in pet chinchillas (Chinchilla lanigera) in China. Parasitol. Int, 64, 339-341 (2015).

36. Li, Q. et al. Molecular investigation of Cryptosporidium in small caged pets in northeast China: host specificity and zoonotic implications. Parasitol. Res, 115, 2905-2911 (2016).

37. Chen, J. et al. Genetic characterizations of Cryptosporidium spp. from pet rodents indicate high zoonotic potential of pathogens from chinchillas. One. Health, 13, 100269 (2021).

38. Li, J. et al. Molecular characterization of Cryptosporidium spp. and Giardia duodenalis in experimental rats in China. Parasitol. Int, 77, 102127 (2020).

39. Zhao, W. et al. Prevalence and diversity of Cryptosporidium spp. in bamboo rats (Rhizomys sinensis) in South Central China. Int. J. Parasitol. Parasites Wildl, 9, 312-316 (2019).

40. Li, F. et al. Common occurrence of divergent Cryptosporidium species and Cryptosporidium parvum subtypes in farmed bamboo rats (Rhizomys sinensis). Parasit. Vectors, 13, 149 (2020).

41. Feng, Y. \& \&Xiao, L. Molecular Epidemiology of Cryptosporidiosis in China. Front. Microbiol, 8, 1701 (2017).

42. Ryan, U. et al. Identification of novel Cryptosporidium genotypes from the Czech Republic. Appl. Environ. Microbiol, 69, 4302-4307 (2003).

43. Li, F. et al. Different distribution of Cryptosporidium species between horses and donkeys. Infect.Genet. Evol, 75, 103954 (2019). 
44. Robinson, G., Elwin, K. \& Chalmers, R. M. Unusual Cryptosporidium genotypes in human cases of diarrhea. Emerg. Infect. Dis, 14, 1800-1802 (2008).

45. Xiao, L. et al. Subtype analysis of Cryptosporidium specimens from sporadic cases in Colorado, Idaho, New Mexico, and lowa in 2007: widespread occurrence of one Cryptosporidium hominis subtype and case history of an infection with the Cryptosporidium horse genotype. J. Clin. Microbiol, 47, 30173020 (2009).

46. Elwin, K. et al. The epidemiology of sporadic human infections with unusual cryptosporidia detected during routine typing in England and Wales, 2000-2008. Epidemiol. Infect, 140, 673-683 (2012).

47. Feng, Y. et al. Cryptosporidium genotypes in wildlife from a New York watershed. Appl. Environ. Microbiol, 73, 6475-6483 (2007).

48. Ziegler, P. E. et al. Prevalence of Cryptosporidium species in wildlife populations within a watershed landscape in southeastern New York State. Vet. Parasitol, 147, 176-184 (2007).

49. Montecino-Latorre, D., Li, X., Xiao, C. \& Atwill, E. R. Elevation and vegetation determine Cryptosporidium oocyst shedding by yellow-bellied marmots (Marmota flaviventris) in the Sierra Nevada Mountains. Int. J. Parasitol. Parasites Wildl, 4( 171-177 (2015).

50. Atwill, E. R., Phillips, R., Pereira, M. D., Li, X. \& McCowan, B. Seasonal shedding of multiple Cryptosporidium genotypes in California ground squirrels (Spermophilus beecheyi). Appl. Environ. Microbiol, 70, 6748-6752 (2004).

51. Pereira, M., Li, X., McCowan, B., Phillips, R. L. \& Atwill, E. R. Multiple unique Cryptosporidium isolates from three species of ground squirrels (Spermophilus beecheyi, S. beldingi, and S. lateralis) in California. Appl. Environ. Microbiol, 76, 8269-8276 (2010).

52. Li, X. et al. Cryptosporidium rubeyi n. sp.(Apicomplexa: Cryptosporidiidae) in multiple Spermophilus ground squirrel species. Int. J. Parasitol. Parasites Wildl, 4, 343-350 (2015).

53. Stenger, B. L. et al. North American tree squirrels and ground squirrels with overlapping ranges host different Cryptosporidium species and genotypes. Infect. Genet. Evol, 36, 287-293 (2015).

54. Deng, L. et al. First identification and multilocus genotyping of Giardia duodenalis in pet chipmunks (Eutamias asiaticus) in Sichuan Province, southwestern China. Parasit. Vectors, 11, 199 (2018).

55. Ma, X., Wang, Y., Zhang, H. J., Wu, H. X. \& Zhao, G. H. First report of Giardia duodenalis infection in bamboo rats. Parasit. Vectors, 11, 520 (2018).

56. Qi, M. et al. Multilocus genotyping of potentially zoonotic Giardia duodenalis in pet chinchillas (Chinchilla lanigera) in China. Vet. Parasitol, 208, 113-117 (2015).

57. Cui, Z. et al. Occurrence and multi-Locus analysis of Giardia duodenalis in coypus (Myocastor coypus) in China. Pathogens, 10, 179 (2021).

58. Fantinatti, M., Bello, A. R., Fernandes, O. \& Da-Cruz, A. M. Identification of Giardia lambliaassemblage $E$ in humans points to a new anthropozoonotic cycle. J. Infect. Dis, 214, 1256-1259 (2016).

59. Gherman, C. M., Kalmár, Z., Györke, A. \& Mircean, V. Occurrence of Giardia duodenalis assemblages in farmed long-tailed chinchillas Chinchilla lanigera (Rodentia) from Romania. Parasit. Vectors, 11, 86 (2018). 